\title{
THE SURVEY OF ACCOUNTING VARIABLES EFFECT ON INCOMESMOOTHING IN STOCK EXCHANGE COMPANIES
}

\author{
M. Y. Mohammadi ${ }^{1}$ and M. H. Arman ${ }^{2}$ \\ ${ }^{1}$ Department of Accounting, Tabas branch, Islamic Azad University, Tabas, Iran \\ ${ }^{2}$ Department of Management, Najafabad, Islamic Azad University, Najafabad, Iran
}

Published online: 16 July 2016

\begin{abstract}
:
In the present study the effects of company size, income-ability, institutional proprietorship, financial leverage and income rate have been surveyed as accounting variables on the income smoothing of the companies accepted in Tehran's securities market. The study has investigated 146 companies accepted in Tehran's securities market during the years from 2001 to 2013. Firstly, the sample companies were classified into smoothed and non-smoothed according to the Eckel's index and then it has been dealt with the study hypotheses test by taking advantage of Hussmann and Lamer tests. The results of the study indicated that the relationship between the company size, income-ability, institutional proprietorship and financial leverage with income smoothing has been confirmed but the relationship between income-ability and income smoothing has not been confirmed.
\end{abstract}

Keywords: income smoothing, company size, income-ability, institutional proprietorship

Author Correspondence, e-mail: author@gmail.com

doi: http://dx.doi.org/10.4314/jfas.v8i2s.29

\section{Study proposition:}

Management owns considerable options in selecting the various methods for recording financial events within the generally accepted accounting principles framework. For example, there are 
various accepted methods regarding depreciation from among which the manager can choose one. Also, management can schedule the financial activities for instance deferring one sale or performing optional expenditures. Due to this very flexibility manager can systematically influence the income reported from one year to another and smooth it (Koch, 1981).

In Beidleman's idea (1973) the options existing regarding the accounting and incorporating the incomes and expenditures creates opportunities for income smoothing. The size and the timing of the optional incomes and costs play a significant role in income smoothing process. The optional items are those which are under the control of the management and it can defer them, omit them or accelerate their record and identification. Omission or reduction of the costs and expenditures related to many of the disbursements especially during the bad and unsuccessful years and increasing them during the good and successful years is considered as a favorable method of practice for many of the optional costs and expenses. Also, deferring or accelerating special kinds of incomes is common practice in many of the companies. While the shareholders appoint managers to maximize their wealth, the managers within the framework of representativeness theory and the existence of interest conflicts which is a natural and by-product of representativeness relationship, try to maximize their own riches. Thus, shareholders usually sign salary and benefit contracts with the managers to maximize the company value, prevent from the managers' dodging away their responsibilities and also the reduction of the shareholder-manager interests conflict. Such contracts mostly include bonus plans and the stock purchase options. Therefore, the managers' wealth increases with two factors: the increase in the stock price and granting them with bonuss (Hassas Yeganeh, 2006).

Therefore, the amount of the received bonus can be a motivating factor for the senior managers. Other motivational factors in managers for income smoothing can be income variations, liability contracts, deviation in operational activities, income tax. The relationship between such variables and income smoothing has also been investigated in Iran. Income smoothing is defined as the conscious reduction of the income level fluctuations in a manner that the company income seems normal. Managers smooth income due to different reasons. One of the main objectives in income smoothing is the creation of a more stable processwith the purpose of supporting the higher payable income level. The more stable incomeprocess can be conceived as a lower risk which leads to higher stock price and lower liability costs. The other objective in income smoothing is the tendency of the business entity manager for increasing the investors' predictability power and 
the reduction of the company risk. Due to the increase in the income stability and the reduction of its fluctuations investors can have a more precise prediction of the future incomes (PoorHeydari and Aflatooni, 2007).

The objective of the present study is the survey of the relationship between the accounting variables and income smoothing in the companies accepted in Tehran's securities market. Income smoothing is a type of conscious action taken by management and by taking advantage of certain tools in accounting in order for the income fluctuations to be reduced. According to the abovementioned subjects, the main question of the study is put forth as follows:

Is there a significant relationship between the accounting variables and income smoothing in the companies accepted in Tehran's securities market?

\section{Study background:}

Healy (1985) in a study entitled "the effect of bonus plans on accounting decisions", expresses getting access to the intra-organizational information for acquiring the bonus plans as the reason behind the managers' tendency toward income smoothing. Based on the results obtained from this study, the method the management makes use of and implements optional accrual variables as a tool for maximizing income differs according to the type of the management bonus plan.

Darrough et al (1997) investigated the income management in Japanese companies during the years from 1989 to 1992. They used optional accrual items scale to smooth income (dependent variable) and they evaluated the effects of the five following independent variables on income smoothing, which are: 1. liability contract (liability to equity ratio) 2. Policy costs (total assets and the number of proprietors and owners), 3. Bonus and rewards variable, 4. External financing (cumulative income to total assets ratio) and internal financing (it is in an inverse relationship with external financing), 5.ownership structure. The bigger the Japanese companies in size, the more staff members they have, the higher the tax rate and the higher the percentage of the financial organizations and institutions; the more the Japanese managers make use of the income decreasing accrual items and the higher the liability ratio, the more the managers' bonuses, the more the ownership percentage of the investors and brokers and the lower the managers' ownership percentage, the managers tend to make a more use of income increasing accrual items. The results indicate that the Japanese managers use income increasing accrual items to increase income and to financially raise funds from exogenous sources. On average, the liability hypothesis was not confirmed in Japanese environment and it seems that the total assets and the 
number of employees are good indicators of the policy costs variable and their related hypotheses can be confirmed. The hypotheses related to the investing individuals' ownership were rejected, but the results showed that the companies with higher brokers' ownership have made a greater use of the income increasing accrual items to exhibit a positive image of the company.

Defond and Park (1997) surveyed the current income and expected income effects on the optional accrual items behavior in their studies and they predicted that the managers try income smoothing as a resort to reduce their possibility of being discharged from their occupations. They selected 97 companies during the years from 1984 to 1994 and they divided these companies into four groups of companies with high current performance, companies with low current performance, companies with high future performance and companies with low future performance. They determined the high and low performance by comparing the "income before smoothing divided by the total assets at the beginning of the period" with the "industrial average of the same very scale", they dealt with their study hypotheses tests by taking advantage of multivariate regression in which the optional accrual items were the dependent variable and the current and future performance was the independent variable. The independent variables were expressed in the form of dummy variables and they took a value equal to unity in case their performance was good and zero if their performance was bad. Also, the company size to liability ratio (natural assets logarithm) and the past optional accrual items (the previous period optional accrual items divided by the assets from the period before the last period) were considered as control variables. They came to this conclusion that when the current performance is low and the future performance is high the mean and the median of the optional accrual items are negative; also, when the current performance is high and the future performance is low the optional accrual items' mean and median is positive; also, when the current performance is high and the future performance is low the optional accrual items' mean and median are negative; both of which are consistent with the income smoothing by managers. The liability to previous period's accrual items ratio is in a positive relationship with the company size and in a negative relationship with optional accrual items.

Chaney et al (1997) surveyed the characteristics of the companies the managers of which deal with income smoothing about perpetual and stable income making by making use of the optional accrual items in a period of time from 1980 to 1992. They applied Jones' adjusted model to 
calculate the optional accrual items and they took advantage of the following two methods to divide the companies into income smoothing and income non-smoothing:

Outcome method: the dividing scale here is the variance ratio. To calculate this ratio, firstly, the input operating cash flow total variance and the non-optional accrual items during five years prior to the current year arecalculated for each test period; then the reported income will be calculated in a similar manner (i.e. during 5 years before the current year). Variance ratio is equal to: Variance ratio $=$ variance (operating cash + non-optional accrual items) $/$ (income) variance The larger this ratio there would be more evidences of smoothing. Then, by putting the variance ratio in a descending order the companies the variance ratio of which situates in the upper third are regarded as a income smoothing companies and the companies the variance ratio of which positions in the lower third are considered as non-smoother companies.

1. Behavior approach: the companies are divided in to income smoothers and non smoothers based on their behavior. That is to say that if they behave according to the smoothing hypothesis they are income smoothing companies and otherwise they are non-smoothing companies. Corresponding to the smoothing hypothesis, if the income prior to the optional accrual items be higher than the last year's reported income the optional accrual items are predicted to have a negative sign and if it be lower the optional accrual items are predicted to have a positive sign. Then, for dividing the companies into two smoothing and non-smoothing groups there exists two approaches: 1. Short-term and 2. Long-term. In short term, if a company has acted corresponding to the smoothing hypothesis for the year $t$, then it would be regarded as non-smoothing. In the long-term, the company behavior will be studied not only in the current period but it will also be investigated for all of the test years under study. If the company has acted according to the income smoothing hypothesis in $70 \%$ of the studied years, it would be considered as incomesmoothing company otherwise, it is a non-smoothing company. Then, by comparing the two study population's averages and regression analysis it was concluded that the income smoothing companies are larger companies; have a higher output and higher optional accrual items. The fact that these companies enjoy higher returns conforms to the previous researches such as the studies performed by Chaney and Lewis (1995) and Trueman and Titman (1989) who expressed that income smoothing is a tool for transferring the company's higher quality. Also, the results of the present study show that the companies with higher liability ratio have higher tendencies and motivation for income smoothing. 
Ahmed et al (2005) in their study entitled as "job security and income smoothing", studied the relationship between job security and smoothing. They made use of optional accrual items as a scale for income smoothing in their study and they predicted that the job security amount is in a negative relationship with the environment in which the companies strive. In this test, there measures of job security were applied which are reflexive of the environmental ambiguity (competition, product sustainable and income variations) and the companies were divided into four groups as was divided by Defond and Park, and the "operating cash flow minus depreciation divided by total assets" was used as the current period performance measure. The future performance is also equal to the analysts' estimation according to the future incomes divided by total assets at the beginning of the period. They applied the multivariate regression model to test their study hypotheses in which smoothing (optional accrual items) was the dependent variable and competition, product sustainable and income variations were the independent variable and financial leverage variables (debit to total assets ratio), company size (equity market value natural logarithm) and accrual items standard deviation (in 10 years) were control variables. Competition level is calculated via the four companies' concentration ratio, in a manner that the sum of the industry four biggest companies' sales is divided by the entire companies' sales in the industry. The larger this ratio the lower would be the competition level. To better interpret this idea, this ratio is inserted with a negative sign in the model. Also, the manufacturing industries are divided into two industrial groups of sustainable and non-sustainable products (if the product is sustainable the sustainability variable of the product takes a value equal to 1 and otherwise it is $0)$. The results show that when the future income is high and the current income is low, the optional accrual items are positive and the job security indices coefficients are also positive; however, the coefficient related to the competition variable is not statistically significant. Also, there is a negative relationship between the financial leverage and company size and the relationship between accrual items standard deviation and income smoothing is positive. The positive relationship between optional accrual items and job security variables may result from the great deal of income variations which is accompanied with much concerns regarding the job security and positive optional accrual items. Also, when the current income is too much and the future income is low, on average, managers transfer the current income to the future periods, which is an indicator of income smoothing. Also, results indicated that the job security-related coefficients were negative and the direct relationship between income smoothing and job security 
is confirmed. Anyhow, the overall results are supportive of this hypothesis that the income smoothing level is in relationship to the job security. The higher the lack of job security, the income smoothing level would be higher. In other words, the managers of the companies struggling in competitive industries produce sustainable commodities and their operational environment ambiguity is greater, and they try to perform income smoothing more through optional accrual items. That is because they are more worried about job security.

Anwer et al (2006) in a study entitled "job security and income smoothing" evaluated the income smoothing and job security roles and the factors influencing them. The study variables were the competitiveness level, the sustainability of the products manufactured and the rate of industry need for investment. The results of the study are indicative of the matter that income smoothing is in a direct relationship with competition level, the manufactured products sustainability and required investment in every industry and it is in an indirect relationship with job security.

Ibrahim et al (2006) in a study entitled "the related factors to the income smoothing methods: a comparative study between Malaysia and the east western Asian countries", dealt with the contrastive analysis of the income smoothing methods in Indonesia, Singapore, Philippine, and Thailand. A sample comprising of 1028 companies in a time span from 1999 to 2003 were investigated. The study results imply income smoothing in the countries of east western part of Asia. The results evaluation and analysis signified that there was a determining discrepancy among the income smoothing methods in those countries. In Malaysia, the companies' incomes and life cycle (age) were factors related to the income smoothing while in Singapore, growth, size and financial leverage were more prominent factors. In Thailand, Indonesia and Philippine the companies' income and size were in a significant relationship with income smoothing methods.

\section{Study hypotheses:}

According to the aforementioned subjects, the followings are posed as the study hypotheses:

First hypothesis: there is a significant relationship between company size and income smoothing in the companies accepted in Tehran securities exchange market.

Second hypothesis: there is a significant relationship between profitability and income smoothing in the companies accepted in Tehran Securities exchange market.

Third hypothesis: there is a significant relationship between institutional ownership and income smoothing in the companies accepted in Tehran Securities exchange market. 
Fourth hypothesis: there is a significant relationship between liability to asset ratio and income smoothing in the companies accepted in Tehran Securities exchange market.

Fifth hypothesis: there is a significant relationship between profitability ratio and income smoothing in the companies accepted in Tehran Securities exchange market.

\section{Study population and sample:}

The study population comprises of all of the companies accepted in Tehran Securities Exchange Market till the date 01/01/2013, and step-by-step the companies which fulfill the following criteria were selected as the study sample:

- The companies should not have a long duration of interactional cessation.

- The companies should have sufficient information for performing the tests.

- They should not have changed their fiscal year.

The study time span is from 2002 to 2013 (a 12-year period). The studied companies are the companies which have been actively participating in Tehran securities exchange market. By surveying the companies accepted in Tehran securities exchange market and exerting the abovementioned conditions and limitations the total number of companies selected for the model estimation and hypotheses test reached 146 companies.

\section{Study territory:}

\section{Spatial dimension:}

The spatial dimension of the study is the companies accepted in Tehran securities exchange market.

\section{Temporal dimension:}

Study temporal dimension includes the financial statements of the companies accepted in securities exchange market during the years from 2002 to 2013.

\section{Study variables:}

the present study variables alike the other studies are comprised of three groups of independent, dependent and control variables, the measurement methodology of which will be presented in the following sections.

\section{Income smoothing:}

Dependent variable is income smoothing which compares the operating profit variations I with the sales variations $\mathrm{S}$ and it has been measured by taking advantage of Eckel's index. Although 
there are other indices, but we think the Eckel's index is more superior due to the following reasons:

- Eckel's index measures profit manipulations without resorting to subjective judgments in order to predict income and estimate costs.

- This index makes use of the information from several periods of time (time series) in lieu of the information for one specific period for calculations (Ashari, 1994).

Eckel's index can be calculated as follows:

Relation (1): income smoothing via Eckel's index $=\mathrm{CV}$ I/ CV S

$\mathrm{CV}$ : variations coefficient for the variable during several intended periods (which is obtained by dividing the intended variable's standard deviation by the same variable's mean).

\section{Independent variable (s):}

Company size: it is calculated from the following relation:

Relation (2): company size is calculated via the natural logarithm of the company j's assets in the year $\mathrm{t}$.

Earningsare obtained by the following relation:

Relation (3): it is obtained via income to total assets ratio of the company $\mathrm{j}$ at the year $\mathrm{t}$.

Institutional proprietorship: it is obtained by the following relation:

Relation (4):

To calculate the institutional ownership amount the entire shares at the disposal of the banks and insurance companies, holdings, investing companies, pension funds, finance companies and investment funds, governmental institutions and organizations and public corporations is divided by the entire issued shares and the institutional ownership percentage of amount is calculated.

Financial leverage: it is obtained via the following relation:

Relation (5): it is calculated via the liability to total assets ratio of the company $\mathrm{j}$ in the year $\mathrm{t}$.

Income-ability rate: it is obtained via the following relation:

Relation (6): the current period Income-ability minus the last period Income-ability divided by the last period's Income-ability of the company $\mathrm{j}$ in the year $\mathrm{t}$.

\section{Study model:}

Relation (7): $\quad$ Smoothing ${ }_{i t}=\alpha_{0}+\beta 1$ size $_{i t}+\beta_{2}$ Incomeability $_{i t}+\beta_{3}$ l-ownership $_{i t}+\beta_{4}$ lev ${ }_{i t}+\beta_{5}$ Rate Incomes $_{i t}+\epsilon_{i t}$

Where, in the above equation, 


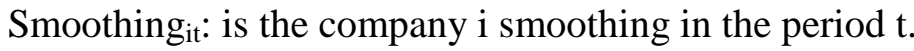

Size: is the company i's size in period $t$.

Income-ability: company i profitability in the period t.

I-ownership: company i profitability in period t.

Lev.: company i financial leverage in period $t$.

Rate-incomes: company i profitability rate in period t.

\section{Data analysis:}

\section{Descriptive statistics:}

After data collection and calculation of the variables used in the present study, each of the variable's descriptive parameters is calculated separately. These parameters include information related to the central indices such as mean, median, minimum, maximum, and the information related to the scattering indices as well, such as standard deviation, kurtosis and skewness. According to the above-mentioned subjects and the material presented in the third chapter, the data used in the present study are of the pooling type. Table 1 tabulates the descriptive statistics of the variables studied for 146 companies included in the study sample and accepted in securities exchange market for a time span from 2002 to 2013 for a 12-year period.

Table 1. Study model variables' descriptive statistics

\begin{tabular}{|l|r|r|r|r|l|}
\hline & \multicolumn{1}{|l|}{ Size } & \multicolumn{1}{l|}{$\begin{array}{l}\text { Income- } \\
\text { ability }\end{array}$} & Ownership & \multicolumn{1}{l|}{ Leverage } & \multicolumn{1}{l|}{$\begin{array}{l}\text { Income } \\
\text { rate }\end{array}$} \\
\hline Mean & 5.737523 & 0.154123 & 0.424351 & 0.652118 & $6.28 \mathrm{E}-07$ \\
\hline Median & 5.662950 & 0.129000 & 0.370750 & 0.662800 & $2.35 \mathrm{E}-07$ \\
\hline Maximum & 8.056000 & 0.833100 & 1.000000 & 1.095700 & $1.56 \mathrm{E}-05$ \\
\hline Minimum & 4.336800 & -0.312700 & 0.000000 & 0.029600 & $-6.79 \mathrm{E}-06$ \\
\hline $\begin{array}{l}\text { Standard } \\
\text { deviation }\end{array}$ & 0.592033 & 0.140935 & 0.340553 & 0.169000 & $1.29 \mathrm{E}-06$ \\
\hline
\end{tabular}

Source: study findings

Among the central measures illustrated here, mean is one of the most important ones which is indicative of the distributions equilibrium point or gravity center. Mean is an appropriate index for showing the data centrality. For example, the mean company size equal to (5.737523)is an indicator that most of the data related to such a variable have been located around this point. Scattering indices are generally a measure for determining the data scattering amount from one 
another or their scattering rate in relation to the mean. One of the most important indices in scattering which is an optimum condition for inputting variable to the regression model is the standard deviation. As it is observed in tables (1-4), the variables' standard deviations are not zero and they satisfy such a condition. In the study population under investigation, the highest value of this parameter belongs to the income rate variable (1.29) and the lowest value of the parameter belongs to income-ability (0.140935).

To estimate the study model and for the purpose of selecting from the pooling or tabulated data methodologies we made use of the Lamer F-test, which is explained below.

\section{Lamer's F-test:}

Firstly, it is necessary o perform the statistical tests for the elaboration of the data typology. Lamer f-test results in table (2) have been given for each of the study models. To estimate the model, the data application method is either tabulate or pooling. F-value possibility for the current study that is to say the survey of the accounting variables effect on income smoothing is lower than 0.05 in the companies accepted in stock exchange market, therefore, the study null hypothesis implying that data pooling is rejected for the study model.

Table 2. The results of Lamer F-test

\begin{tabular}{|l|l|l|l|}
\hline Test type & Value & Value possibility & Result \\
\hline Lamer F-test & 224.1 & 0.0003 & Tabulation strategy \\
\hline
\end{tabular}

Source: study findings

\section{Hussmann test:}

According to Lamer f-test, it is now necessary to perform Hussmann test for the determination of the type of the tabulate data. As it is observed from table 3, the results obtained from Hussmann's test for the model indicate that the data are tabulate and of fixed effects. The possibility amount related to this test value is lower than $5 \%$, therefore, the study model is to be estimated based on the intended variables according to the tabulate data approach and with fixed effects.

Table 3. Hussmann test results

\begin{tabular}{|l|l|l|l|}
\hline Test type & Value & $\begin{array}{l}\text { Value } \\
\text { possibility }\end{array}$ & Result \\
\hline Hussmann & 34.10 & 0.0001 & $\begin{array}{l}\text { Tabulation strategy with fixed } \\
\text { effects }\end{array}$ \\
\hline
\end{tabular}

Source: study findings 


\section{The results of the study model estimation:}

After performing the required statistical tests, the final results obtained from the study models estimation are presented here to determine the data applicability and insure the fitted pattern accuracy. Based on the results obtained from Lamer F-test and Hussmann test the study model was estimated based on the tabulated data with fixed effects. The results obtained from the model estimation are illustrated in table 4 which is used to test the effect of accounting variables on the income smoothing in the stock exchange market companies. On the other hand, the significance level obtained here for the entire array of the smaller independent variables is lower than test level of 0.05. Also, this idea is confirmed by taking Durbin-Watson statistical value into consideration that there is no autocorrelation between the components, since the Durbin-Watson value is in the range of 1 and 3 . 
Table 4. The results related to the study estimation

\begin{tabular}{|c|c|c|c|c|c|}
\hline Variable & Symbol & $\begin{array}{l}\text { Estimated } \\
\text { coefficient }\end{array}$ & $\begin{array}{l}\text { Standard } \\
\text { deviation }\end{array}$ & t-value & p-value \\
\hline$y$-intercept & $\mathrm{C}$ & 24.20447 & $4.42 \mathrm{E}-13$ & $5.47 \mathrm{E}+13$ & 0.0000 \\
\hline $\begin{array}{l}\text { Company } \\
\text { size }\end{array}$ & construct & $-2.54 \mathrm{E}-12$ & $7.08 \mathrm{E}-14$ & -35.88373 & 0.0000 \\
\hline $\begin{array}{l}\text { Income- } \\
\text { ability }\end{array}$ & $\begin{array}{l}\text { Income- } \\
\text { ability }\end{array}$ & $3.77 \mathrm{E}-13$ & $2.10 \mathrm{E}-13$ & 1.800552 & 0.0720 \\
\hline $\begin{array}{l}\text { Institutional } \\
\text { ownership }\end{array}$ & 1-ownership & $-1.22 \mathrm{E}-12$ & $1.14 \mathrm{E}-13$ & -10.65905 & 0.0000 \\
\hline $\begin{array}{l}\text { Financial } \\
\text { leverage }\end{array}$ & Lev. & $4.71 \mathrm{E}-13$ & $1.45 \mathrm{E}-13$ & 3.245685 & 0.0012 \\
\hline $\begin{array}{l}\text { Income } \\
\text { ratio }\end{array}$ & Income-rate & $-3.61 \mathrm{E}-07$ & $1.98 \mathrm{E}-08$ & -18.26732 & 0.0000 \\
\hline $\begin{array}{l}\text { F- } \\
\text { value: } 1.86\end{array}$ & $\begin{array}{l}\text { f-value } \\
\text { significance }\end{array}$ & & 0.0000 & $\begin{array}{l}\text { Determination } \\
\text { coefficient }\end{array}$ & 0.78 \\
\hline $\begin{array}{l}\text { Durbin- } \\
\text { Watson } \\
\text { value }\end{array}$ & 2.77 & $\begin{array}{l}\text { Number of } \\
\text { observations }\end{array}$ & 158 & & \\
\hline
\end{tabular}

Source: study findings

Finally, the study multivariate regression model has been estimated based on the tabulated data approach with fixed effects and the model hypotheses results are explicated as follow:

\section{Study hypotheses test results:}

After the study models are estimated we deal with the survey and interpretation of the study hypotheses test results and the followings are explanations and interpretations regarding the six study hypotheses.

\section{The study first hypothesis test results:}

The study first hypothesis is as below: 
Null hypothesis: there is no significant relationship between company size and income smoothing.

Contrastive hypothesis: there is a significant relationship between company size and income smoothing.

As it is indicated by the results from table (4), the amount of P-value (0.0000) for the company size of the companies accepted in Tehran's securities exchange market is lower than the error level of 0.05 . Therefore, $\mathrm{H}_{0}$ is rejected and it can be concluded that there is a significant relationship between the company size and income smoothing. The first hypothesis results correspond to the results of the study obtained by Jahanshad and Amiri (2013). Also, the results of the present study conform to the results obtained in the study performed by Javadi Mazdeh (2010).

\section{Second hypothesis results:}

The second hypothesis of the present study states that:

Null hypothesis: there is not a significant relationship between earnings and income smoothing.

Contrastive hypothesis: there is a significant relationship between earnings and income smoothing.

As it is observed from the results illustrated in table 4, the amount of P-value (0.0720) for income-ability variable is more than error level of 0.05 in the companies accepted in Tehran's securities exchange market. Therefore, $\mathrm{H}_{0}$ hypothesis is not rejected and it can be concluded that there is no significant relationship between earnings and income smoothing. The results of the second hypothesis correspond to the results obtained by Shoorvarzi and Pahlavan (2011) and the study results obtained by Jahanshad and Amiri (2013).

\section{The results of the study third hypothesis:}

The third hypothesis states that:

Null hypothesis: there is no significant relationship between institutional ownership and income smoothing.

Contrastive hypothesis: there is a significant relationship between institutional ownership and income smoothing.

As it can be seen from the results given in table (4), the amount of P-value (0.0000) for the institutional ownership variable in the companies accepted in Tehran's securities exchange market is lower than the error level of 0.05 . So, $\mathrm{H}_{0}$ is not rejected and it can be concluded that 
there is no significant relationship between institutional ownership and income smoothing. The results obtained in the third hypothesis are consistent with the results obtained in the study by Mollanazari and Karimi (2008) and Jahanshad and Amiri (2013).

\section{Fourth hypothesis test results:}

The fourth hypothesis is expressed as below:

Null hypothesis: there is no significant relationship between liability to asset ratio and income smoothing.

Contrastive hypothesis: there is a significant relationship between liability to asset ratio and income smoothing.

As it is indicated by the results obtained from table (4), the amount of P-value (0.0012) for the financial leverage variable in the companies accepted in Tehran's securities exchange market is lower than the error level of 0.05 . Therefore, $\mathrm{H}_{0}$ is rejected and it can be concluded that there is a significant relationship between the financial leverage and income smoothing. The results of the hypothesis four conform to the results obtained by Nowravesh et al (2006) and the study performed by Jahanshad and Amiri (2013).

\section{Fifth hypothesis test results:}

The fifth hypothesis is as below:

Null hypothesis: there is a significant relationship between income rate and income smoothing.

Contrastive hypothesis: there is no significant relationship between income rate and income smoothing.

As it is observed from the results given in table 4, the amount of P-value (0.0000) for the income rate variable of the companies accepted in Tehran's securities exchange market is lower than the error level of 0.05 . Therefore, $\mathrm{HO}$ is rejected and it can be concluded that there is a significant relationship between income rate and income smoothing. The results obtained in the present study are consistent with the results obtaind by Jahanshad and Amiri (2013) and 'Etemadi and Javadimazdeh (2008).

\section{Study constraints:}

Taking steps towards reaching a goal has always been accompanied with limitations and constraints. Sometimes reaching to the goal is done in a slacking manner. Research as a process for getting to the objective of solving the study problem cannot be excluded from this principle. So, in this section of the study we try to inform the reader of the existing constraints in order to 
be able to generalize the study results with more concern and caution and to have a more justified judgment regarding the study process and results. In line with this, the current study constraints can be expressed as below:

- Income smoothing evaluation is one of the most tedious and difficult tasks in the process of the study. Measuring income smoothing in companies is a very complicated and labor-intensive job. According to this matter that we made use of operating cash variations coefficient in the present study to measure the income smoothing scale and all of the variations coefficients are averaged in the present study any index other than the operating cash flow can exert changes on the study results.

- The current study results have been obtained by taking advantage of the data gathered from the companies accepted in Tehran's securities exchange market and all of the companies have not been studied. Thus, there is a need for being cautious in generalizing the results obtained from the current study to all of the companies accepted in Tehran's securities exchange market.

- Some of the information related to the financial statements of some of the companies accepted in stock exchange market was incomplete and imperfect as a result of some reasons, for instance some of their existing files were altered or omitted and therefore they were excluded from the study population.

- Here, the information of the non-stock market companies were not acquired and applied due to their unavailability.

- Data extracted from the companies' financial statements has not been inflation-adjusted. In case of the adjustment of the mentioned information there is a possibility for the results to differ.

- Because, the current study time span is from 2002 to 2013, there is a need for being cautious regarding generalizing the results to the previous or future periods.

\section{Study suggestions:}

Majority of the managers are not theoretically familiar with the subject of income smoothing and they may take actions to perform income smoothing for the sole purpose of creation of positive results without being aware of the possible adverse effects. Therefore, most of the managers try income smoothing to increase or decrease their earnings without having information regarding the income smoothing theoretical nature via controlling the business and economical activities such as accelerating or deferring commodity delivery or by issuing bills or increasing or decreasing the inventory at the end of the period or by changing the optional selectable 
accounting methods like the change in the depreciation calculation method. Of course, income smoothing should have a favorable effect on the stock value and cost reduction, since when a fixed interest rate is reported by the company shareholders feel more confident. There are numerous reasons cited for the intentional income smoothing and researchers know many factors effective on the income smoothing behavior. Along with this, it is suggested to the share and stock buyers to get informed of the amount of the reported income as of the real income before taking steps to purchase stock shares and they are recommended to evaluate the amount of the smoothed income via the effective mechanisms proposed in the present study and if the company manager had made use of a lower array of optional items in his or her financial reports then there would be a possibility to think of buying the company's stock.

Also, accounting standards compilers are recommended to make the managers aware of the consequences of income smoothing via establishing a standard implying the devastative effects of the income smoothing.

\section{Suggestions for future research:}

In this section, suggestions for future and further research are presented as below:

1. The effect of income management on accounting variables

2. The effect of accrual items on other accounting variables

3. The effect of optional accrual items on accounting variables

4. The effect of non-optional accrual items on accounting variables

5. The effect of accounting variables in income smoothing companies and income non-smoothing companies

\section{REFERENCES:}

[1] Hsasyganh, Yahya (2005). "Philosophy audit " Cultural and Scientific Publications, Tehran.

[2] Pourheydar O, Abbas A. "The motivation of smoothing the listed companies in Tehran Stock Exchange". Evaluation of accounting and auditing, the thirteenth year, 2006, 44:70-55.

[3] Ahmed S. A, Gerald J. L, Jian Z," Job security and income smoothing: An empirical test of the Fudenberg and Tirol(1995) Model, www.ssrn.com. 2005

[4 ] Anwer S.A, Gerald J.L, Jian Z, "Job Security and Income Smoothing : An Empirical Test of the Fudenberg and Tirole (1995) Model". < http:WWW.SSRN.com>.2006 
[5] Beidleman C.R, "Income Smoothing:The Role of Management". The Accounting Review, 1973, 48(4): 653-667.

[6] DarroughN.Massako,HamidPourjalali and ShahrokhSaudagaran (1997). “ Earnings management in Japanese companies", on Line Avalable at :www.ssrn.com

[7] Defond M. L. C. W. Park (199. "Smoothing Income in Anticipation of Future Earnings". Journal of Accounting and Economics, 1973, 23: 115-139.

[8] Defond M. 1, Subramanyam K. R, “Auditor changes and discretionary accruals" Journal of Accounting and Economics, 1998, 25: 35-67

[9] Chaney P. K, Debra C . J, “ Income smoothing and firm characteristics” , Accounting Enquiries, 1997, 1(7): 83-115.

[10] Healy P.M.. "The Effect of Bonus Schemes on Accounting Decisions". Journal of Accounting and Economics, 1985, 7: 85-107.

[11] Koch S. Bruce, 'Income smoothing: An experiment' ,The Accounting Review, July

[12] Trueman, B. and S. Titman(1988). "An Explanation for Accounting Income Smoothing". Journal of Accounting Research(Supplement), 1981, 26(3):127-139.

\section{How to cite this article:}

Mohammadi M. Y, Arman M. H. The survey of accounting variables effect on incomesmoothing in stock exchange companies. J. Fundam. Appl. Sci., 2016, 8(2S), 1257-1271. 